\title{
Antioxidant Enzymes and Some Trace Metals in Plasmodium Falciparum Infected Pregnant Nigerian Women
}

\author{
Adetola Olusegun Olushola \\ Forestry Research Institute of Nigeria P.M.B 5054 Jericho Hills Ibadan
}

\begin{abstract}
Pregnancy, mostly because of the mitochondria rich placenta is a condition that favours oxidative stress. Reactive oxygen species has been implicated in the pathogenesis of malaria.In the present study, a total of twenty four pregnant women with malaria were compared with twenty six pregnant women without malaria that serve as control groups, the levels of antioxidants enzymes (catalase and total peroxidase ) and some trace metal ( Selenium,Copper,Zinc) were determined. Catalase activity was significantly lower in pregnant women with malaria, as compared to their corresponding control. Peroxidase activity was significantly higher in pregnant women with malaria, as compared to their corresponding control. Selenium which can be used as a proxy for peroxidase determination was found to be significantly higher in pregnant women with malaria as compared to their corresponding control. There were highly positive significant correlation between Selenium and total Peroxidase activity. $\mathrm{r}=1.00 \mathrm{p}=<0.001$. There is increase oxidative stress in plasmodium falciparum infected pregnant women. The pro - oxidant to anti -oxidant equilibrium was found to favour the pro - oxidant.
\end{abstract}

Keywords:Pregnancy,Antioxidants,Freeradical,Redbloodcell.

DOI: $10.7176 / J N S R / 9-9-04$

Publication date:May $31^{\text {st }} 2019$

\section{INTRODUCTION}

Man and malaria seem to have evolved together, today population of malaria may have had their origin in west Africa (P falciparum) and west and central Africa (P.vivax) on the basis of the presence of homozygous alleles for haemoglobin $\mathrm{C}$ that confer protection against $\mathrm{P}$. falciparum and P.vivax respectively[1,18].

The ancestors of the malaria parasites have existed at least half a billion years ago [2].Malaria is generally endemic in the tropics with extension into the subtopics[18]. In 2000, 80\% of cases were in Africa with the remainder clustered in nine countries: India, Brazil, Afghanistan, Sri Lanka, Thailand, Indonesia, Vietnam, Cambodia and China [8].

Human malaria is caused by four species of parasitic protozoa of the genus plasmodium: Plasmodium falciparum, P.vivax, P. Malaria and P.ovale.

Plasmodium falciparum is the predominant species with $120,000,000$ new cases and up to $1,000,000$ deaths per year globally [17]. Plasmodium falciparum is closely related to malaria parasite of chimpanzees, P.reichenowi and these two are more closely related to the malaria parasites of birds than that of other animals [18].

Malaria in pregnancy is an obstetric, social and medical problem requiring multidisciplinary and multidimensional solution. Pregnant women with malaria constitute $80 \%$ of death due to malaria in Africa [14].

In Africa, prenatal mortality due to malaria is at about 1500 /day, in areas where malaria is endemic $20-40 \%$ of all babies born may have a low birth weight [9].

The physiological changes of pregnancy and the pathological changes due to malaria have a synergistic effect, thus making life difficult for the mother, the child and the treating physician [9].

Pregnant women are more susceptible to malaria, which causes serious adverse effects including abortion, low birth weight and maternal anaemia [16].

Free radicals are constantly formed as a by - product of aerobic respiration and other metabolic reactions. Most of the oxygen (O2) used during the oxidation of dietary organic molecules is converted into water, but a significant amount (1-2\%) is diverted into highly reactive oxygen species (ROS), mainly the superoxide, hydroxyl, peroxyl and hydroperoxyl anion [3]. Superoxide dismutase is present in all aerobic cells; it converts superoxide to hydrogen peroxide which in turn is reduced to water by the antioxidant enzyme catalase and glutathione peroxidase [3].

The first line of defence that the body has against free radicals is the enzyme known as Superoxide Dismutase or (SOD).

In the process of removing superoxide free radicals, SOD rarely operates alone. It requires the enzyme called "Catalase "(CAT) to remove hydrogen peroxide molecules which are by - products of the reactions created by SOD [10]. Integrated in all red blood cells, CAT removes hydrogen peroxide from the tissues, preventing both cell damage and more importantly the formation of other more toxic free radicals [5]. The ability of CAT to mob O2 species from lysing the red blood cells prevents haemolytic anaemia which is effective in malaria control [11]. 


\subsection{LIFE CYCLE OF HUMAN MALARIA}

The life cycle of malaria parasites comprises morphologically and antigenically distinct stages that are targeted by stage specific Immunity. Sporozoite are Inoculated by blood - feeding female Anopheles mosquitoes. After 30$60 \mathrm{mins}$ in the blood stream, these uninucleated extracellular stages penetrate hepatocytes and start intense mitotic activity and nuclear division.

The resulting mature multinucleate liver - stage schizont bursts within 9 to 16 days and release thousands of free merozoites into the bloodstream. Two of the human malaria parasite species P.vivax and P.ovale produce dormant liver stages known as hypnozoites that are the sources of relapses weeks or months after the primary infection. Within 1 to $2 \mathrm{~min}$ of release, merozoites invade red blood cells (RBCs) in which over the next 48 or $7 \mathrm{hrs}$ they develop from early to late trophozoites and undergo a further phase of mitotic division which generate erythrocytic-stage schizont. When infected RBCS rupture, each mature schizont releases 8 to 32 merozoites, each of which invades nearby erythrocytes. Fever paroxysms, the hallmark of malaria occur when infected RBCS rupture and release parasite - derived molecules that stimulates the production of pro inflammatory cytokines by the host. After a few cycles some merozoites develop into sexual stages known as gametocytes. When gametocytes are taken up by feeding Anopheles mosquitoes, they mature into male and female gametes and unite to form a zygote in the midnight of the vector.

The precise targets of protective immunity against malaria remain unknown, although present evidence implicate about 20 candidate antigens, most of them polymorphic surface proteins[4]. Because structurally different antigens are expressed during each part of the parasites life cycle, naturally acquired immunity is mostly stage specific. Both antibodies and T-cell response are particularly effective against intracellular liver stage parasites, while antibodies may block host cell division by Sporozoite and merozoites [6]. T-cell help is essential for an effective response but relatively little is known about the additional role of cell mediated immunity in the clearance of blood stage malaria parasite.

The present study aim to elucidate the role of antioxidant enzymes and some trace metals in the prevention of malaria.

\subsection{MATERIALS AND METHODS}

2.1 COLLECTION OF BLOOD SAMPLE: With permission from Lagos State University Teaching Hospital, blood samples were collected from pregnant women attending antenatal clinic. Samples were collected by venipuncture.

\subsection{SCREENING FOR MALARIA PARASITE}

Thick and thin blood films were made on both slides; slides with frosted ends were used to facilitate labelling. To ensure good staining, plastic bulb was used to collect the blood sample then spread the thin film using a smooth edged slide spreader on a clean grease free microscopic slide.

Using a dark pencil label the slide with date and name of patients allow the blood films to air dry with the slide in a horizontal position.

Then Gemsa stain was used by placing the slide on a rack and cover with methanol, fixed thin film with $0.5 \mathrm{ml}$ of diluted stain $\mathrm{B}$, then immediately add stain $\mathrm{A}$ and leave for 1 minute.

\subsection{DETERMINATION OF TOTAL PEROXIDE ACTIVITY (TRINDER ET AL. 1960).}

The method of (Trinder et al. 1960) was used for the determination of total Peroxidase activity, expressed in units based upon the rate of oxidation of pyrogallol. The reaction rate was determined by an increase in absorbance at $560 \mathrm{~nm}$ resulting from the decomposition of hydrogen peroxide by the peroxidase.

One unit results in the decomposition of $\mathrm{H} 2 \mathrm{O} 2$ per unit at $25 \mathrm{oC}$ and $\mathrm{PH} 7.0$ under the specified condition.

\section{PROCEDURE}

The total peroxidase activity was measured spectrophotometrically as described by (Trinder et al 1960). Briefly, 100 of serum sample was mixed with $1.4 \mathrm{ml}$ phenol aminoantipyrine solution and $1.5 \mathrm{ml}$ of $0.2 \mathrm{~m}$ potassium phosphate buffer at $\mathrm{PH} 7.0$ containing $0.0017 \mathrm{M}$ hydrogen peroxide( $\mathrm{H} 2 \mathrm{O} 2)$ substrate after 4 minutes of equilibration at $25 \mathrm{oc}$. A mixture lacking the serum sample replaced with distilled water was then measured against blank over $5 \mathrm{~min}$ at $1 \mathrm{~min}$ interval. The change in absorbance per minute was estimated.

\subsubsection{DETERMINATION OF CATALASE ACTIVITY}

PRINCIPLE: Serum catalase was determined by the rate of disappearance of hydrogen peroxide according to the protocol of Weber et al 1972.

PROCEDURE: 100UL serum was added to $100 \mathrm{ul}$ of $0.05 \mathrm{~N}$ potassium phosphate buffer (PH7.0) containing hydrogen peroxide and previously equilibrated for 5 minutes at $25 \mathrm{oc}$. The resulting volume was adjusted to $3.0 \mathrm{ml}$ with addition of 1900 ul of distilled water followed by vortexing.

Absorbance was then read against the blank for $3 \mathrm{~min}$ at $30 \mathrm{sec}$ intervals to allow calculation of decrease in absorbance per minute (DA 240/min) using the portion of the curve. 


\subsection{DETERMINATION OF PLASMA LEVEL OF TRACE METAL}

Plasma levels of elements, currently, cu, se, $\mathrm{zn}$ and $\mathrm{mn}$ were determined with flame atomic absorption spectrophotometer (AAS) using a direct method as described by Kaneko [7]. The method is based on the principle that atoms of the element when aspirated into AAS vaporizer and absorbed light of the same wavelength as that emitted by the element when in the excited state.

\subsection{STATISTICAL ANALYSIS}

Main data and standard deviation of samples were determined. Correlation studies between antioxidant enzymes (Total peroxidase and catalase) using the persons correlation coefficient at $99 \%$ level of confidence.

\subsection{RESULTS AND DISCUSSION}

In table 3.1 the level of catalase in pregnant women with malaria was (6.27 \pm 3.08$)$ lower than their corresponding control group $(6.72 \pm 1.13)$ in the primigravidae group. However, the difference in the mean \pm S.E was not significant.

In the secondigravidae the catalase level for the pregnant women with malaria was $(3.23 \pm 1.15)$ lower than their corresponding control groups $(4.0 \pm 1.07)$, through the difference in the mean \pm S.E was not significant. In the multigravidae the catalase level for the pregnant women with malaria $(6.31 \pm 1.39)$ lower than their corresponding control group $(6.57 \pm 1.17)$, though the difference in the mean \pm S.E was not significant.

In table 3.1,the peroxidase level in pregnant women with malaria were ( $12.62 \pm 3.67,9.21 \pm 2.36)$ higher than their corresponding control groups $(4.44 \pm 1.05,2.17 \pm 0.36,0.00)$, though the difference in their mean $\pm \mathrm{S}$.E was not significant, in the primigravid a, secondigravidae and multigravidae groups.

In table 3.1, the level of Selenium in pregnant women with malaria for primigravid, secondigravidae and multigravidae were $(106.30 \pm 4.74,93.38 \pm 9.93,90.54 \pm 5.18)$ higher than their corresponding control $(66.50 \pm$ $2.22,75.50 \pm 3.07,69.13 \pm 2.76)$. However, their differences in mean $\pm \mathrm{S}$.E was significant for primigravid $(0.01)$, multigravidae (0.01) and insignificant for the secondigravidae.

The level of copper in pregnant women with malaria was $(66.00 \pm 3.70)$ lower than their corresponding control $(66.50 \pm 2.22)$ in the primigravid a. However, the difference in mean $\pm \mathrm{SE}$ was not significant.

In table 3.1 , the level of zinc in the pregnant women with malaria were lower $(89.55 \pm 5.58,100.34 \pm 6.83)$ in the secondigravidae and multigravidae respectively, than their corresponding control $(117.18 \pm 5.45,119.90 \pm 5.95)$. However, their difference in mean $\pm \mathrm{SE}$ was significant for secondigravidae and not significant for multigravidae. In the primigravid the Zinc level for pregnant women with malaria was $(96.25 \pm 10.68)$ higher than their corresponding control. Although, the difference in mean $\pm \mathrm{SE}$ was not significant.

In table 3.2, the levels of peroxidase in Selenium and Zinc in the pregnant women with malaria were higher in their primigravid than their corresponding secondigravidae. However their mean $\pm \mathrm{SE}$ was not significant.

The levels of catalase and copper in pregnant women with malaria were lower in the primigravidae than their corresponding secondigravidae.

The levels of peroxidase, Selenium and Zinc in pregnant women with malaria were higher in their primigravid than their corresponding multigravidae although, their mean $\pm \mathrm{SE}$ was not significant.

The levels of catalase, copper and Zinc in pregnant women with malaria were lower in their secondigravidae than their corresponding multigravidae. However, there mean \pm was not significant. The level of peroxidase in the secondigravidae was same as that of multigravidae. However, their corresponding mean $\pm \mathrm{SE}$ was not significant.

In table 3.3, the level of catalase in pregnant women with malaria was (6.37 \pm 3.02$)$ lower than their corresponding control $(6.60 \pm 3.02)$. However, corresponding mean $\pm \mathrm{SE}$ were not significant, for the nulliparity

In the primiparity, the level of catalase was $(3.23 \pm 1.15)$ lower than their corresponding control $(3.75 \pm 0.81)$, although their corresponding mean \pm was not significant.

In the multiparty, the catalase level in pregnant women was $(6.31 \pm 1.39)$ lower than their corresponding control (6.32 \pm 1.47$)$. Although their corresponding mean $\pm \mathrm{SE}$ was not significant.

In table 3.3, the peroxidase level in pregnant women with malaria were $(6.97 \pm 3.95,10.99 \pm 2.15,9.21 \pm 2.36)$ higher than their corresponding control $(2.11 \pm 1.12,2.51 \pm 0.35,3.60 \pm 1.38)$ in the nulliparity, primiparity and multiparty. However, their corresponding mean \pm were not significant for nulliparity and multiparty but significant for primiparity.

In table 3.3, the Selenium level in pregnant women with malaria were $(106.5 \pm 106.01,93.25 \pm 0.64$, $92.06 \pm 0.75)$ higher in the nulliparity, primiparity and multiparty than their corresponding control $(90.29 \pm 0.79$, $77.60 \pm 0.69,68.50 \pm 0.72)$. However, their corresponding mean $\pm \mathrm{SE}$ were all significant.

In table 3.3 , the copper level in pregnant women with malaria were $(66.00 \pm 3.69,68.25 \pm 4.55,74.67 \pm 2.33)$ lower than their corresponding control $(70.00 \pm 1.27,70.80 \pm 1.68,75.33 \pm 2.29)$ in the nulliparity, primiparity and multiparty. However, their corresponding mean $\mathrm{SE} \pm$ were not significant.

In table 3.3, Zinc level in pregnant women with malaria was $(96.25 \pm 21.36)$ lower than their corresponding control (129.29 \pm 23.45$)$ in the nulliparity. However, their corresponding mean $\pm \mathrm{SE}$ was not significant. 


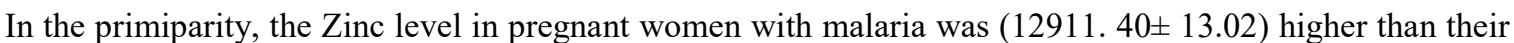
corresponding control (89.50 \pm 129117.66$)$. Although their corresponding mean \pm SE was significant.

In multiparty, the Zinc level in pregnant women with malaria was (100.34 \pm 21.58$)$ lower than their corresponding control (118.98 \pm 24.87$)$. Although, their corresponding mean $\pm \mathrm{SE}$ was significant.

In table 3.4, the level of Selenium in pregnant women with malaria was higher in their nulliparity than their corresponding primiparity. However, their mean $\pm \mathrm{SE}$ was not significant.

The levels of catalase, peroxidase, copper and zinc in pregnant women with malaria were lower in their mean $\pm \mathrm{SE}$ was not significant for peroxidase and copper but was significant for zinc.

In table 3.4, the level of Selenium was higher in their nulliparity than their corresponding multiparity, although their corresponding mean $\pm \mathrm{SE}$ was not significant. The levels of catalase, peroxidase, copper and zinc were lower in their various nulliparity than their corresponding multiparty. However, their mean $\pm \mathrm{SE}$ was not significant for catalase peroxidase and zinc but was significant for copper.

In table 3.4, the level of peroxidase, Selenium and Zinc were higher in their various primiparity than their corresponding multiparty. However, their $\pm \mathrm{SE}$ was not significant. The copper and catalase level were lower in the primiparity than their corresponding multiparty. However their corresponding mean $\pm \mathrm{SE}$ was not significant.

In table 3.5 , the level of catalase in pregnant women with malaria were $(1.34 \pm 1.06,5.10 \pm 0.95,5.00 \pm 1.73)$ lower than their corresponding control $(1.66,5.53 \pm 0.92,6.00 \pm 1.52)$ for the first trimester, second trimester and third trimester. However, their corresponding mean \pm were not significant.

In table 3.5, the level of peroxidase in pregnant women with malaria were $(14.08 \pm 0.76,10.33 \pm 2.40,7.92$ $\pm 2.21)$ higher than their corresponding control $(1.80 \pm 0.00,2.85 \pm 0.50,4.26 \pm 1.47)$. In the $1^{\text {st }}, 2^{\text {nd }}$ and $3^{\text {rd }}$ trimester. However, their corresponding mean $\mathrm{SE} \pm$ were not significant.

In table 3.5, the level of Selenium in pregnant women with malaria were $(98.50 \pm 1.0,84.83 \pm 7.88,100.45 \pm$ 4.93) higher than their corresponding control $(65.50 \pm 0.00,73.16 \pm 2.52,72.50 \pm 2.92)$ in the $1^{\text {st }}, 2^{\text {nd }}$ and $3^{\text {rd }}$ trimester. However, their corresponding mean \pm SE were not significant.

In table 3.5 , the level of copper in pregnant women with malaria was $(69.00 \pm 1.00)$ same as their corresponding control $(69.00 \pm 0.01)$ in the $1^{\text {st }}$ trimester. However, their corresponding mean $\pm \mathrm{SE}$ was not significant.

In the second trimester, the level of copper in pregnant women with malaria was (72.67 \pm 1.74$)$ higher than their corresponding control $(72.11 \pm 1.31)$; though their corresponding mean \pm SE was not significant.

In the third trimester, the level of copper in pregnant women with malaria was $(71.00 \pm 2.53)$ lower than their corresponding control $(73.17 \pm 2.75)$, though their corresponding mean \pm was not significant.

In table 3.5, the level of Zinc in pregnant women with malaria were $(70.00 \pm 15.00,100.13 \pm 4.97,93.24$ $\pm 6.19)$ lower than their corresponding control $(130.00 \pm 4.86,121.12 \pm 4.88,110.43 \pm 9.22)$ in the $1^{\text {st }}, 2$ nd and $3^{\text {rd }}$ trimester. However, their corresponding mean \pm SE was not significant for $1^{\text {st }}$ trimester, but was significant for $2^{\text {nd }}$ and $3^{\text {rd }}$ trimester.

In table 3.6, the levels of catalase, copper and zinc in pregnant women with malaria were lower in their various first trimesters than their corresponding second trimester. However, their mean \pm SE was not significant.

The levels of peroxidase and Selenium were higher in their various first trimesters than their corresponding second trimester. However their mean $\pm \mathrm{SE}$ was not significant.

In table 3.6, the levels of catalase, Selenium, Copper and zinc were lower in their various first trimesters than their corresponding second trimester. However their mean \pm SE was not significant.

In table 3.6 the levels of catalase and Selenium were lower in their various second trimesters than their corresponding third trimester. However, their corresponding mean $\pm \mathrm{SE}$ was not significant.

The levels of peroxidase, copper and zinc were higher than their second trimester than their corresponding third trimester. However their mean $\pm \mathrm{SE}$ was not significant.

In table 3.7, the level of catalase in pregnant women with malaria were $(6.42 \pm 2.11,3.81 \pm 0.45)$ lower than their corresponding control $(6.58 \pm 1.15,4.25 \pm 0.87)$ in the young and matured adult respectively. However, their corresponding mean $\pm \mathrm{SE}$ was not significant.

In table 3.7, the level of peroxidase in pregnant women with malaria were $(10.85 \pm 2.41,9.23 \pm 1.93)$ higher than their corresponding control $(3.00 \pm 0.44,2.91 \pm 1.10)$ in the young and matured adult respectively. However their corresponding mean $\pm \mathrm{SE}$ was not significant.

In table 3.7, the level of Selenium in pregnant women with malaria were $(88.1 \pm 6.44,98.47 \pm 5.25)$ higher than their corresponding control $(72.5 \pm 2.32,72.32 \pm 3.16)$ in the young and matured adults respectively. However, their corresponding mean $\pm \mathrm{SE}$ was not significant for young adult and significant for matured adult.

In table 3.7, the level of copper in pregnant women with malaria was (73.10 \pm 2.70$)$ higher in the young adult than their corresponding control $(70.00 \pm 1.25)$. However, their corresponding mean $\pm \mathrm{SE}$ was not significant.

In the matured adult, the level of copper in pregnant women with malaria was $(70.79 \pm 1.16)$ lower than their corresponding control (74.83 \pm 1.73$)$, though their corresponding mean \pm SE was not significant.

In table 3.7, the Level of Zinc in pregnant women with malaria were $(94.45 \pm 5.22,99.81 \pm 5.71)$ lower than 
their corresponding control $(123.69 \pm 3.83,110.00 \pm 7.51)$ in the young and matured adult. However, their corresponding mean $\pm \mathrm{SE}$ was significant for young adult and not significant in matured adult.

In table, 3.8, the level of peroxidase and copper were higher in their various young adult than their corresponding matured adult. However, their corresponding mean \pm SE was not significant.

The catalase, Selenium and Zinc levels in pregnant women with malaria were lower in their various young adult than their corresponding matured adult. However, their mean \pm SE was not significant.

A total of 24 P. falciparum malaria infected pregnant subject were compared with 26 control patient. Pregnant women with malaria had been reported to exhibit low catalase activity [15].

This has been confirmed by the present study, in the primigravidae, secondigravidae and multigravidae the level of serum catalase was low in the subject as compared with the control. Also in the nulliparity, primiparity and multiparity, the various trimester and age distributions, the serum catalase activity were low.

Peroxidase activity was also observed to be high in the gravidious state, parity, trimester and age distributions. This was confirmed by [15] that pregnant malaria patients had high peroxidase activity in the subject as compared with the control.

In our study, it was observed that Selenium a trace metal that our bodies use to produce glutathione peroxidase, an enzyme that serves as a natural antioxidant was high in the subject in their various gravidious state, parity state, trimester state and age distribution. This is in accordance with the suggestion that free radical formation during plasmodium haemolysis of the RBC cell membrane triggers the production of Selenium [12].

Copper is a trace metal involved in the function of several cuproenzymes that are essential for the conversion of Ferric ion to the ferrous form [13]. In the present study, the levels of copper were low in the subjects in the primigravidae, but the levels were high in both the secondigravidae and multigravidae. The parity state shows a different trend as the levels of serum copper was consistently low in the nulliparity, primiparity and multiparity hence; low serum concentration was associated with malaria in pregnancy.

Also the level of serum copper in the $1^{\text {st }}$ trimester was not significantly different in the subject as compared with the control, but the level was high during the second trimester and during the third trimester, the serum level of copper was low, this is in accordance with the fact that low serum copper concentrations in pregnant women during gestation was associated with high risk for plasmodium infection [9].

Zinc level was high in the primigravidae subject but the level of serum zinc was low in the subject secondigravidae and multigravidae. In the nulliparity, the serum zinc was low, high in the primiparity and low in the multiparity of the subject. The case was different in the trimester as the serum zinc level was low for all the trimester. In the age distribution of pregnant women the level of serum zinc was also consistently low.

\subsection{CONCLUSION}

There was increased oxidative stress in plasmodium falciparum infected pregnant women. There were reduced catalase activity and increased total peroxidase activity in infected pregnant women. Thus, Pro - oxidant to Anti - oxidant equilibrium was found to be in favour of the Pro-oxidant.

Hence, Selenium was highly positively correlated with peroxidase and lowly correlated with copper. Also, copper was lowly correlated with peroxidase and catalase has no correlation with peroxidase.

Also, that Selenium can be used as a direct index for the measure of peroxidase activity.

\section{ACKNOWLEDGMENT}

Author is grateful to Dr. Segun Adeola of Lagos State University for support he rendered in the sample collection stage.

\section{REFERENCES}

[1] Al-Gadel, A.A.. (1986). Malaria in the Sudan. In Proceedings of the conference on malaria in Africa. Ed. Buck, A.A Washington D.C. Am Inst. Biological Sci, 77:156-159.

[2] Bouyyil, A.A., Lallo, D. and Muntac, C.D.(2000). History of Malaria in Africa. Am Inst Bio. Sci, 19 : 120 129.

[3] Burton, G.J., E. Hempstock. and Jauniank.(2003). Oxygen, early embryonic metabolism and radical mediated embryopathies. J. Reprod. Biomed, $6: 84-96$.

[4] Bonelo, R.Y., Cederber, A.S. and Alves, S.S.(2000). The placental transfer and concentration difference in maternal and neonatal serum uric acid at parturition comparison of normal pregnancies and gestation. Bio. Res Preg prenatal $8: 35-39$.

[5] Beekman, T.O., Heidiger, M.L., Fisher, R.L. and Shearer, J.W.(1998). Anaemia and iron deficiency. J.clin. Nutr. 55: 985-988.

[6] Genton, B.C., Jauniaux, E., Cotton, F.V. and Stordeur, P.(2002). Protein and enzyme pattern in fluid cavities of first trimester gestational sac. Relevance of the absorptive role of the secondary folk Salk. Mol Hun Reprod, no.4, pp. 857-862, 
[7] Knapen, M.F., Zusterzeel, P.L. and W.H. Peters.(1999). Glutathione and glutathione related enzymes in reproduction. A Review Eur. J. Obstetric gynecol Report Biol, 82 :171-184.

[8] Lopez, M.F., Kasten, B.L and Maldon, W.L.(2005). Interaction of Female Child to environmental bacterial infection. J .Clin Chem, 16: 211-224.

[9] MacLeod, O.(1990). Parasitic infection during pregnancy. J .Clin. infect. Dis, 174 :811-812.

[10] McCormick, F.E., Mclaran, C.E., Gordeuk, V.R. and McLaren, G.D.(1996). Malaria and pregnancy placenta cytokine expression and its relationship to intra uterine growth retardation. J. infect. Dis, 180 : 1987-1993.

[11] Mitchell, J.M., Gibson, R.S., Culliana, T.R.(2003). The impact of malaria infection in diet on the anaemia status of rural pregnant Malawian women. Eur. J. Clin Nutr. 53: 792-801.

[12] Menendez, C. (1995). Malaria during pregnancy. A priority area of malaria research and control. $11: 178$ 183.

[13]Newton, C.R., Kirkham, F.J. and Peshu, N.(1991). Intracranial pressure in African Children with Cerebral malaria. 337: 573-576.

[14] Newman, R.D., Jimmy, D. and Kebede, D.(2003). Burden of malaria during pregnancy in areas of stable and unstable transmission in tropics during a non - epidemic year. J. Infect. Dis, . 187 :1765-1772.

[15] Rogerson, S.J., Chaluwka, E. and Mhango, C.G.(2000). Malaria and anaemia in antenatal women in Blantyre. Am. J. Trop. Med. Hyg, $62: 335-340$.

[16] World Health Organization, Geneva, 1983.

[17] World Health Organization, Geneva, 1990.

[18] World Health Organization, Geneva, 1998.

TABLE 3.1

ANTIOXIDANT ENbZYMES AND SOME TRACE METALS IN PREGNANT WOMEN WITH MALARIA AND THIER CORRESPONDING CONTROL IN THIER VARIOUS GRAVIDIOUS STATE.

\begin{tabular}{|c|c|c|c|c|c|c|c|c|c|c|c|c|}
\hline \multirow[b]{2}{*}{ PARAMETER } & \multicolumn{4}{|c|}{ PRIMIGRAVIDEA } & \multicolumn{4}{|c|}{ SECONDIGRAVIDAE } & \multicolumn{4}{|c|}{ MULTIGRAVIDAE } \\
\hline & SUBJECT & CONTROL & $\mathrm{T}$ & $\mathbf{P}$ & SUBJECT & CONTROL & $\mathrm{T}$ & $\mathbf{P}$ & SUBJECT & $\begin{array}{l}\text { CON } \\
\text { TROL }\end{array}$ & $\mathrm{T}$ & $\mathbf{P}$ \\
\hline CATALASE & $6.37 \pm 3.08$ & $\begin{array}{l}6.7240 \pm \\
0.13\end{array}$ & -0.07 & $\mathrm{P}=0.05$ & $\begin{array}{l}3.2 \pm \\
1.15\end{array}$ & $\begin{array}{l}3.9 \pm \\
1.07\end{array}$ & 1.55 & $P=0.05$ & $6.307 \pm 1.39$ & $\begin{array}{l}6.57 \pm \\
1.17\end{array}$ & 0.03 & $P=0.05$ \\
\hline PEROXIDASE & $12.62+3.67$ & $\begin{array}{l}4.44 \pm \\
1.05\end{array}$ & 3.57 & 0.37 & $9.21 \pm 2.27$ & $\begin{array}{l}2.17 \pm \\
0.36\end{array}$ & 3.00 & 0.20 & $\begin{array}{l}9.21 \pm \\
2.36\end{array}$ & 0.00 & 0.71 & 0.52 \\
\hline SELENIUM & $106.30 \pm 4.74$ & $66.50 \pm 2.22$ & 5.16 & 0.01 & $93.38+9.93$ & $75.50 \pm 3.07$ & 2.18 & 0.12 & $\begin{array}{l}90.54 \pm \\
5.78\end{array}$ & $\begin{array}{l}69.13 \pm \\
2.76\end{array}$ & 3.12 & 0.01 \\
\hline COPPER & $\begin{array}{l}66.00 \pm \\
3.70\end{array}$ & $\begin{array}{l}66.50 \pm \\
2.22\end{array}$ & -0.1 & 0.93 & $\begin{array}{l}72.00 \pm \\
2.44\end{array}$ & $\begin{array}{l}71.22 \pm \\
1.40\end{array}$ & -0.62 & 0.55 & $\begin{array}{l}76.73 \pm \\
1.77\end{array}$ & $\begin{array}{l}76.40 \pm \\
1.92\end{array}$ & -0.70 & 0.5 \\
\hline ziNC & $96.25 \pm 10.68$ & $91.25 \pm 20.71$ & 0.25 & $P>0.01$ & $\begin{array}{l}89.55 \pm \\
5.58\end{array}$ & $\begin{array}{l}117.18 \pm \\
5.45\end{array}$ & -2.61 & $P=0.05$ & $\begin{array}{l}100.34 \pm \\
6.83\end{array}$ & $\begin{array}{l}119.09 \pm \\
5.95\end{array}$ & -2.19 & $P=0.05$ \\
\hline
\end{tabular}

TABLE 3.2

ANTIOXIDANT ENZYMES AND SOME TRACE METALS IN PREGNANT WOMEN WITH MALARIA IN THIER VARIOUS GRAVIDIOUS STATE.

\begin{tabular}{|l|l|l|l|l|l|l|l|l|l|l|}
\hline \multicolumn{2}{|l|}{ PARAMETER } & \multicolumn{2}{l|}{ CATALASE } & \multicolumn{2}{l|}{ PEROXIDASE } & \multicolumn{2}{l|}{ SELENIUM } & \multicolumn{2}{l|}{ COPPER } & ZINC \\
\hline N & T & $\mathbf{P}$ & $\mathbf{T}$ & $\mathbf{P}$ & $\mathbf{T}$ & $\mathbf{P}$ & $\mathbf{T}$ & $\mathbf{P}$ & $\mathbf{T}$ & $\mathbf{P}$ \\
\hline $\begin{array}{l}\text { PG1S- } \\
\text { SG2S }\end{array}$ & 0.31 & $\mathrm{P}>0.05$ & 0.85 & 0.44 & -0.02 & $\mathrm{P}>0.05$ & -0.61 & $\mathrm{P}>0.05$ & 1.22 & $\mathrm{P}>0.05$ \\
\hline $\begin{array}{l}\text { PG1S- } \\
\text { MG3S }\end{array}$ & 0.31 & $\mathrm{P}>0.05$ & 0.71 & 0.52 & 1.37 & $\mathrm{P}>0.05$ & -3.36 & $\mathrm{P}>0.0 .5$ & -0.58 & $\mathrm{P}>0.05$ \\
\hline $\begin{array}{l}\text { SG2S- } \\
\text { MG3S }\end{array}$ & - & $\mathrm{P}>0.05$ & 0.45 & 0.67 & 0.05 & $\mathrm{P}>0.05$ & 0.97 & $\mathrm{P}>0.05$ & -1.38 & $\mathrm{P}>0.05$ \\
\hline
\end{tabular}

PG1S = PRIMIGRAVIDITY SUBJECT

$\mathrm{SG} 2 \mathrm{~S}=$ SECONDIGRAVIDITY SUBJECT

MG3S = MULTIGRAVIDITY SUBJECT 


\section{TABLE 3.3}

ANTIOXIDANT ENZYMES AND SOME TRACE METALS IN PREGNANT WOMEN WITH MALARIA AND THIER CORRESPONDING CONTROL IN THIER VARIOUS PARITY STATE.

\begin{tabular}{|c|c|c|c|c|c|c|c|c|c|c|c|c|}
\hline \multirow[b]{2}{*}{ PARAMETER } & \multicolumn{4}{|c|}{ NULLIPARITY } & \multicolumn{4}{|c|}{ PRIMIPARITY } & \multicolumn{4}{|c|}{ MUL TIPARITY } \\
\hline & SUBJECT & CONTROL & $\mathrm{T}$ & $\mathbf{P}$ & SUBJECT & CONTROL & $\mathrm{T}$ & $\mathbf{P}$ & SUBJECT & CONTROL & $\mathrm{T}$ & P \\
\hline CATALASE & $\begin{array}{l}6.37 \pm \\
3.08\end{array}$ & $\begin{array}{l}5.6 \pm \\
1.45\end{array}$ & -0.07 & $P>0.05$ & $\begin{array}{l}3.23 \pm \\
1.15\end{array}$ & $\begin{array}{l}3.74 \pm \\
740.81\end{array}$ & 1.38 & $\mathrm{P}>0.05$ & $\begin{array}{l}6.301 \pm \\
1.39\end{array}$ & $\begin{array}{l}6.32 \pm \\
1.47\end{array}$ & -0.006 & $P>0.05$ \\
\hline PEROXIDASE & $\begin{array}{l}6.97 \pm \\
3.95\end{array}$ & $\begin{array}{l}2.11 \pm \\
1.12\end{array}$ & 1.03 & 0.38 & $\begin{array}{l}10.99 \pm \\
2.15\end{array}$ & $\begin{array}{l}2.51 \pm \\
0.35\end{array}$ & 3.72 & 0.005 & $\begin{array}{l}9.21 \pm \\
2.36\end{array}$ & $\begin{array}{l}3.60 \pm \\
1.38\end{array}$ & 3.01 & 0.20 \\
\hline SELENIUM & $\begin{array}{l}106.5 \pm \\
1.01\end{array}$ & $\begin{array}{l}70.29 \pm \\
0.79\end{array}$ & 5.26 & 0.013 & $\begin{array}{l}93.25 \pm \\
0.637\end{array}$ & $\begin{array}{l}77.60 \pm \\
0.69\end{array}$ & 3.95 & 0.003 & $\begin{array}{l}92.06 \pm \\
0.75\end{array}$ & $\begin{array}{l}68.00 \pm \\
0.72\end{array}$ & 2.66 & 0.03 \\
\hline COPPER & $\begin{array}{l}66.00 \pm \\
3.69\end{array}$ & $\begin{array}{l}70.00 \pm \\
1.27\end{array}$ & -1.04 & 0.38 & $\begin{array}{l}68.25 \pm \\
4.55\end{array}$ & $\begin{array}{l}70.50 \pm \\
1.68\end{array}$ & 0.50 & 0.63 & $\begin{array}{l}74.67 \pm \\
2.33\end{array}$ & $\begin{array}{l}75.33 \pm \\
2.29\end{array}$ & 1.35 & 0.24 \\
\hline ZINC & $\begin{array}{l}96.25 \pm \\
21.36\end{array}$ & $\begin{array}{l}129.29 \pm \\
23.45\end{array}$ & 0.25 & 0.82 & $\begin{array}{l}111.40 \pm \\
13.02\end{array}$ & $\begin{array}{l}\text { 89.50土 } \\
17.66\end{array}$ & 2.61 & 0.03 & $\begin{array}{l}100.34 \pm \\
21.58\end{array}$ & $\begin{array}{l}118.78 \pm \\
24.87\end{array}$ & -2.19 & 0.057 \\
\hline
\end{tabular}

\section{TABLE 3.4}

ANTIOXIDANT ENZYMES AND SOME TRACE METALS IN PREGNANT WOMEN WITH MALARIA IN THIER VARIOUS PARITIOUS STATE.

\begin{tabular}{|l|l|l|l|l|l|l|l|l|l|l|}
\hline PARAMETER & CATALASE & \multicolumn{1}{l|}{ PEROXIDASE } & \multicolumn{2}{l|}{ SELENIUM } & \multicolumn{2}{l|}{ COPPER } & ZINC \\
\hline & T & $\mathbf{P}$ & T & P & T & P & T & P & T & P \\
\hline NP1S-PP2S & 0.31 & $\mathrm{P}>0.05$ & -1.38 & 0.26 & -1.075 & $\mathrm{P}>0.05$ & 1.34 & $\mathrm{P}>0.05$ & -5.20 & $\mathrm{P}>0.05$ \\
\hline NP1S-MP3S & -0.31 & $\mathrm{P}>0.05$ & -2.02 & 0.14 & 2.3 & $\mathrm{P}>0.05$ & -5.88 & $\mathrm{P}>0.05$ & -0.24 & $\mathrm{P}>0.05$ \\
\hline PP2S-MP3S & -0.05 & $\mathrm{P}>0.05$ & 0.79 & 0.45 & 0.49 & $\mathrm{P}>0.05$ & -0.144 & $\mathrm{P}>0.05$ & 1,54 & $\mathrm{P}>0.005$ \\
\hline
\end{tabular}

$\begin{array}{ll}\text { NP1S } & \text { NULLIPARITY SUBJECT } \\ \text { PP2S } & =\text { PRIMIPARITY SUBJECT } \\ \text { MP3S } & =\text { MULTIPARITY SUBJECT }\end{array}$

TABLE 3.5

ANTIOXIDANT ENZYMES AND SOME TRACE METALS IN PREGNANT WOMEN WITH MALARIA AND THIER CORRESPONDING CONTROL IN THIER VARIOUS TRIMESTER STATE

\begin{tabular}{|c|c|c|c|c|c|c|c|c|c|c|c|c|}
\hline \multirow[b]{2}{*}{ PARAMETER } & \multicolumn{4}{|c|}{$1^{\text {st TRIMESTER }}$} & \multicolumn{4}{|c|}{$2^{\times 10}$ TRIMESTER } & \multicolumn{4}{|c|}{$3^{20}$ TRIMESTER } \\
\hline & SUBJECT & CONTROL & T & $P$ & SUBJECT & CONTROL & $\mathrm{T}$ & $\mathrm{P}$ & SUBJECT & CONTROL & T & $\mathrm{P}$ \\
\hline CATALASE & $1.34 \pm 1.06$ & 1.66 & 0.00 & 0.00 & $5.10 \pm 0.95$ & $5.53 \pm 0.92$ & 0.4 & 0.7 & $\begin{array}{l}5.07 \pm \\
1,73\end{array}$ & $6.00 \pm 1.52$ & 0.24 & 0.81 \\
\hline PEROXIDASE & $14.08+0.76$ & $1.80 \pm 0.00$ & 0.00 & 0.00 & $10.33 \pm 2.40$ & $2.85 \pm 0.50$ & 2.70 & 0.02 & $7.992+2.21$ & $\begin{array}{l}4.26 \pm \\
1.47\end{array}$ & 1.50 & 0.18 \\
\hline SELENIUM & $98.50 \pm 1.50$ & $65.00 \pm 0.00$ & - & - & $84.83 \pm 7.88$ & $73.16 \pm 2.52$ & 1.18 & 0.26 & $100.45 \pm 4.93$ & $71.50 \pm 2.92$ & -8.50 & 0.08 \\
\hline COPPER & $69.00 \pm 1.00$ & $69.00 \pm 0.01$ & 0.00 & 0.00 & $72.67 \pm 1.74$ & $72.11 \pm 1.31$ & 0.55 & 0.60 & $71.00 \pm 2.53$ & $73.17 \pm 2.75$ & 0.46 & 0.67 \\
\hline zINC & $70.00 \pm 15.00$ & $130.00 \pm 4.86$ & - & - & $100.13 \pm 4.97$ & $121.12+4.88$ & -4.26 & 0.001 & $93.14 \pm 6.19$ & $10.43+9.22$ & -3.23 & 0.02 \\
\hline
\end{tabular}


TABLE 3.6

ANTIOXIDANT ENZYMES AND SOME TRACE METALS IN PREGNANT WOMEN WITH MALARIA IN THIER VARIOUS TRIMESTER STATE

\begin{tabular}{|l|l|l|l|l|l|l|l|l|l|l|}
\hline PARAMETER & CATALASE & PEROXIDASE & \multicolumn{2}{l|}{ SELENIUM } & \multicolumn{2}{l|}{ COPPER } & \multicolumn{2}{l|}{ ZINC } \\
\hline & T & $\mathbf{P}$ & T & $\mathbf{P}$ & T & $\mathbf{P}$ & $\mathbf{T}$ & $\mathbf{P}$ & T & P \\
\hline & & & & & & & & & & \\
\hline TRI1S-TRI2S & -1.31 & $\mathrm{P}>0.05$ & -28.71 & 0.22 & -8.50 & 0.08 & 0.82 & $\mathrm{P}>0.05$ & -1.04 & $\mathrm{P}>0.05$ \\
\hline TRI1S-TRI3S & -1.05 & $\mathrm{P}>0.05$ & 02.60 & 0.23 & 1.40 & $\mathrm{P}>0.05$ & -05.00 & $\mathrm{P}>0.05$ & -15.67 & $\mathrm{P}>0.05$ \\
\hline TRI2S-TRI3S & -0.34 & $\mathrm{P}>0.05$ & 0.92 & 0.38 & -1.05 & $\mathrm{P}>0.05$ & 0.47 & $\mathrm{P}>0.05$ & -0.68 & $\mathrm{P}>0.05$ \\
\hline
\end{tabular}

TRIIS = FIRST TRIMESTER SUBJECT

TRI2S = SECOND TRIMESTER SUBJECT

TRI3S = THIRD TRIMESTER SUBJECT

TABLE 3.7

ANTIOXIDANT ENZYMES AND SOME TRACE METALS IN PREGNANT WOMEN WITH MALARIA AND THIER CORRESPONDING CONTROL IN THIER VARIOUS AGE STATE

\begin{tabular}{|l|l|l|l|l|l|l|l|l|}
\hline & \multicolumn{3}{|l}{ YOUNG ADULT (20-29YRS) } & \multicolumn{3}{l|}{ MATURED ADULT (30 \&ABOVE ) } \\
\hline PARAMETER & SUBJECT & CONTROL & T & P & SUBJECT & CONTROL & T & P \\
\hline CATALASE & $6.42 \pm 2.11$ & $6.5 \pm 1.15$ & 0.78 & 0.50 & $3.81 \pm 0.45$ & $4.25 \pm 0.87$ & 0.88 & 0.4 \\
\hline PEROXIDASE & $10.85 \pm 2.41$ & $3.00 \pm 0.44$ & 3.05 & 0.16 & $9.23 \pm 1.93$ & $2.91 \pm 1.10$ & 2.40 & 0.37 \\
\hline SELENIUM & $88.1 \pm 6.44$ & $72.5 \pm 2.33$ & 1.92 & 0.09 & $98.47 \pm 5.25$ & $72.31 \pm 3.16$ & 3.96 & 0.002 \\
\hline COPPER & $73.10 \pm 2.70$ & $70.00 \pm 1.25$ & 1.11 & 0.30 & $70.79 \pm 1.16$ & $74.833 \pm 1.73$ & -1.76 & 0.11 \\
\hline ZINC & $94.45 \pm 5.22$ & $123.69 \pm 3.83$ & -4.57 & 0.001 & $99.81 \pm 5.71$ & $110.00 \pm 7.51$ & -1.0 & 0.33 \\
\hline
\end{tabular}

TABLE 3.8

ANTIOXIDANT ENZYMES AND SOME TRACE METALS IN PREGNANT WOMEN WITH MALARIA IN THIER VARIOUS AGE STATE.

\begin{tabular}{|l|l|l|l|l|l|l|l|l|l|l|l|}
\hline PARAMETER & CATALASE & \multicolumn{2}{l|}{ PEROXIDASE } & \multicolumn{2}{l|}{ SELENIUM } & \multicolumn{2}{l|}{ COPPER } & \multicolumn{2}{l|}{ ZINC } \\
\hline & T & P & T & P & T & P & T & P & T & P \\
\hline N & & & & & & & & & & \\
\hline YAS-MAS & 1.80 & $\mathrm{P}>0.05$ & 0.57 & 0.58 & -1.25 & $\mathrm{P}>0.05$ & 0.51 & $\mathrm{P}>0.05$ & 0.07 & $\mathrm{P}>0.05$ \\
\hline
\end{tabular}

YAS $=$ YOUNG ADULT SUBJECT

MAS $=$ MATURED ADULT SUBJECT

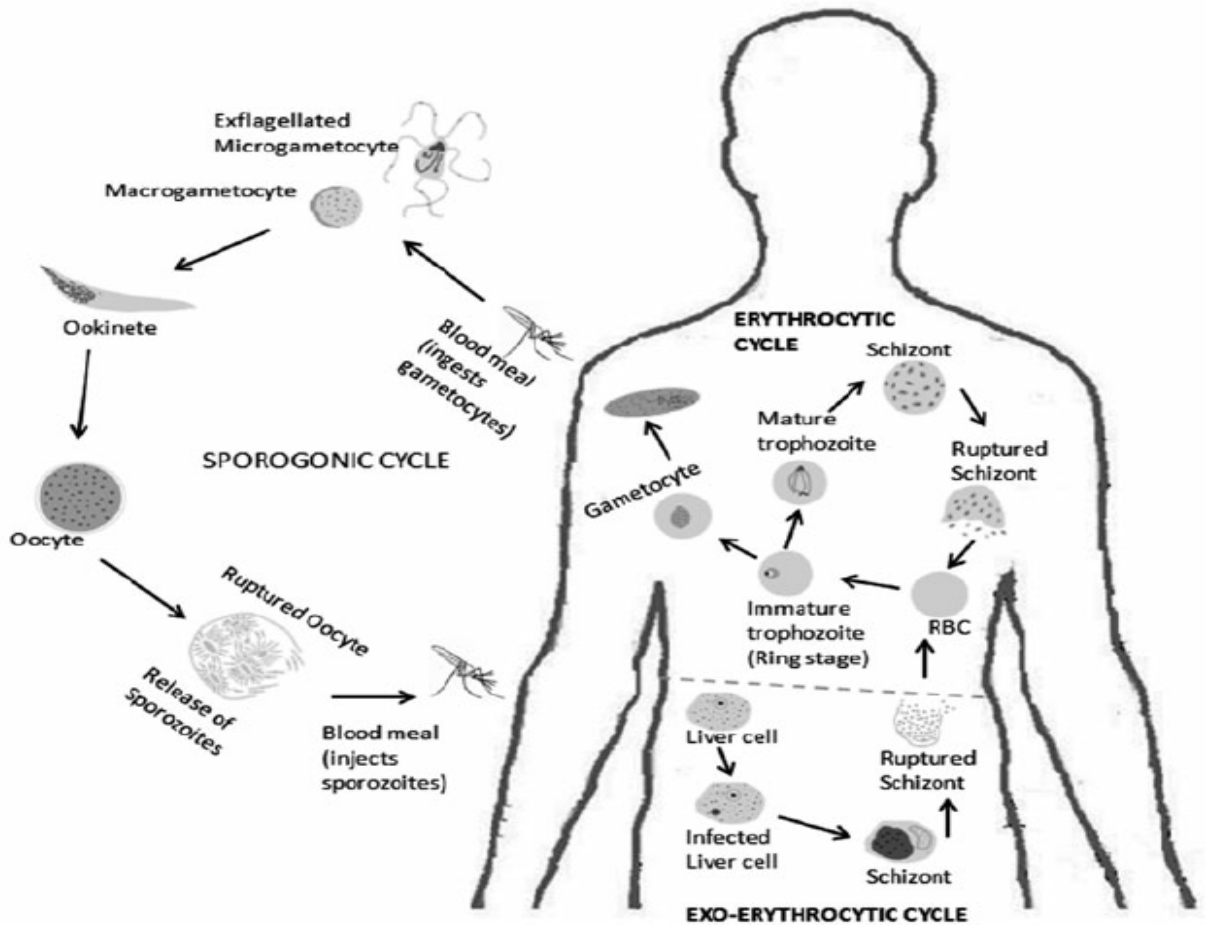

FIG 1: Simplified life cycle of malaria parasites in human hosts. The parasite development within mosquito vector is not represented 